\title{
Perbedaan Kadar HS-CRP Menurut Indeks Massa Tubuh dan Derajat Pramenstrual Syndrome pada Remaja Usia 18 - 24 Tahun
}

\author{
Mega Ade Nugrahmi ${ }^{1}$, Joserizal Serudji ${ }^{2}$, Almurdi ${ }^{3}$ \\ Ilmu Kebidanan, Fakultas Kedokteran, Universitas Andalas, Padang ${ }^{1}$ \\ Obstetri Gynecologi, Fakultas Kedokteran, Universitas Andalas, Padang ${ }^{2}$ \\ Patologi Klinik, Fakultas Kedokteran, Universitas Andalas, Padang ${ }^{3}$ \\ Email: mega_gaulya@yahoo.com
}

\begin{abstract}
Premenstrual syndrome occurs through the mechanism of chronic inflammation. This can be explained through the immune system which plays an important role in many aspects of women's reproductive function, including follicular recruitment, ovulation, implantation, and endometrium (Evans, 2012). The increase in CRP as a marker of inflammatory process/inflammation associated with obesity (Schulz, 2011). Body fat mass, as well as deposits of energy, it also produces adipocytokines and proinflammatory molecules such as interleukin-6 (IL-6) which is a major determinant of CRP gene expression (Wellen, 2003; Nyandak, 2007; Schulz, 2011; Basir, 2012). An increase in inflammatory conditions cause increased hs-CRP protein in the liver. The effect of that increases estrogen levels during the luteal phase which triggers an increase in prostaglandins and causes an inflammatory response. The purpose of this research is to know the difference in the levels of hs-CRP according to Body Mass Index and the degree of premenstrual syndrome. This research is a quantitative research with the kind of analytical research studies. The design of the research was cross sectional study. The study was conducted at the Padang Health Ministry Polytechnic. The population in this study were all fertile women aged 18-24 years who were active in studying at the Padang Health Ministry Polytechnic. The sample of this research were all populations that met the inclusion and exclusion criteria. The results of the research showed a mean difference where the levels of hs-CRP were higher in obese adolescents compared to normal BMI and it also showed a mean difference where the levels of hs-CRP were higher in moderate PMS degrees compared to low PMS degrees with $p<0.05$. There is a significant relationship between the Body Mass Index and the degree of premenstrual syndrome. It is necessary to have a weight loss program in people with obesity and weight control to keep it in ideal condition, so that it can reduce the increase in complaints on premenstrual syndrome.
\end{abstract}

Keywords: Levels of HS-CRP, Body Mass Index, Degree of Pre-Menstrual

\section{PENDAHULUAN}

Pramenstrual syndrome terjadi melalui mekanisme peradangan kronis. Hal ini dapat dijelaskan melalui sistem kekebalan tubuh yang memainkan peran penting dalam banyak aspek fungsi reproduksi wanita, termasuk perekrutan folikuler, ovulasi, implantasi, dan endometrium (Evans, 2012). Pada wanita pramenopause, kadar plasma dan tingkat faktor peradangan endometrium termasuk $C$-reactive protein (CRP), interleukin ( IL) -6, IL-1b, dan tumor necrosis factor-a (TNF- $\alpha$ ) meningkat setelah ovulasi dan tinggi selama menstruasi. Besarnya perubahan siklik pada kekebalan tubuh berbeda antara wanita. Hal inilah yang memicu variasi fungsi kekebalan tubuh yang meningkatkan peradangan sistemik kronis yang berkontribusi langsung pada gejala pramenstruasi (Berbic, 2014).
Peradangan kronis berhubungan dengan gangguan kejiwaan dan somatik yang merupakan keluhan umum yang terjadi pada penderita PMS, dalam hal ini depresi, kegelisahan, migrain, dan nyeri pada perut (Liebregts, 2007; Brennan, 2009; Miller, 2009; Lippi, 2014). Beberapa penelitian saat ini telah mengevaluasi secara langsung hubungan antara gejala peradangan dan PMS. Puder (2006) melaporkan bahwa kadar CRP berhubungan positif dengan tingkat keparahan gejala PMS pada 15 wanita sehat, dan memiliki asosiasi yang paling kuat terhadap gejala PMS yaitu mood dan nyeri.

Penelitian Gold (2015) melakukan analisis faktor yang digunakan untuk mengidentifikasi lima kelompok gejala yang berbeda dari gejala yang dilaporkan. Sampel penelitian memberikan sampel darah puasa dan dilanjutkan dengan melakukan tes high sensitivity C-Reactive 
Protein (hs-CRP). Penggunaan hsCRP dalam mengidentifikasi CRP disarankan karena bersifat stabil dan dapat mendeteksi inflamasi sampai tingkatan terendah (low grade inflammation) (Gansareng, 2015). Penelitian ini juga telah menyesuaikan faktor demografi dan indeks massa tubuh, hasil penelitian CRP yang meningkat dikaitkan dengan kemungkinan kecemasan, perubahan mood, kram (perut, nyeri punggung, sendi dan otot), peningkatan nafsu makan, kembung dan nyeri payudara/ nyeri tekan.

Menurut Puder (2006) terdapat hubungan antara kadar high sensitivity C-Reactive Protein pada wanita usia muda. Selain itu penelitian yang dilakukan oleh Capuron (2010), terdapat korelasi positif antara hs-CRP dengan kecemasan dan depresi, apabila kadar hs-CRP tinggi, dapat diprediksi bahwa tingkat kecemasan dan depresi pun meningkat. Berdasarkan penelitian yang dilakukan oleh Wunder (2006), peningkatan kadar estrogen dapat menstimulasi produksi hs-CRP di hati.

Berdasarkan survei pendahuluan yang dilakukan kepada 10 responden diketahui 7 orang dari 10 responden (70\%) mengalami gejala pramenstrual syndrome diantaranya 4 responden memiliki gejala meliputi perubahan psikologis yaitu mudah tersinggung, kegelisahan, depresi, dan iritabilitas/sensitif. Sedangkan 3 responden memiliki gejala perubahan fisik meliputi kembung perut, nyeri tekan payudara, nyeri kepala dan punggung. Selain daripada itu terdapat 3 orang dari 10 responden $(30 \%)$ memiliki Indeks Massa Tubuh $($ IMT) > 23 yaitu kelebihan berat badan dan lingkar pinggang $>80 \mathrm{~cm}$ yaitu berada pada kategori obesitas.

Berdasarkan uraian data yang telah dikemukakan diatas dan teori mendukung, maka peneliti tertarik untuk melakukan penelitian dengan judul "perbedaan kadar hs-CRP menurut Indeks Massa Tubuh dan derajat pramenstrual syndrome".

Tujuan penelitian ini adalah untuk mengetahui perbedaan kadar hs-CRP menurut Indeks Massa Tubuh dan derajat pramenstrual syndrome.

\section{METODE PENELITIAN}

Penelitian ini merupakan penelitian kuantitatif dengan jenis penelitian studi analitik. Desain penelitian yang digunakan adalah cross sectional study. Penelitian telah dilakukan di Poltekkes Kemenkes Padang. Populasi pada penelitian ini adalah semua wanita usia subur berusia 18-24 tahun yang aktif kuliah di Poltekkes Kemenkes Padang. Sampel pada penelitian ini adalah bagian dari populasi yang memenuhi kriteria inklusi dan eksklusi penelitian. Uji statistik yang digunakan yaitu chi-square.

Hipotesis penelitian ini adalah:

1. Adanya perbedaan kadar hs-CRP pada Indeks Massa Tubuh remaja obesitas dan normal.

2. Adanya perbedaan kadar hs-CRP pada derajat pramenstrual syndrome ringan,sedang dan berat.

3. Adanya hubungan Indeks Massa Tubuh (IMT) dengan derajat pramenstrual syndrome ringan,sedang dan berat.

Penelitian ini telah mendapatkan persetujuan etik dari komite etik. Selama pengambilan data dan publikasi prinsip etika penelitian telah diterapkan.

\section{HASIL DAN PEMBAHASAN}

Berdasarkan tabel 1 diketahui bahwa hasil uji normalitas kadar hs-CRP pada indeks massa tubuh remaja normal dan obesitas serta pada derajat PMS ringan dan sedang berdistribusi normal dengan $\mathrm{p}>0,05$.

Tabel 1. Uji Normalitas Data pada Kadar hs-CRP berdasarkan Indeks Massa Tubuh dan Derajat Pramenstrual Syndrome

\begin{tabular}{clccc}
\hline Variabel & \multicolumn{1}{c}{ Kelompok } & n & Mean \pm SD & p value \\
\hline hs-CRP $(\mathrm{ng} / \mathrm{ml})$ & Normal & 25 & $1150,1 \pm 278,8$ & 0,059 \\
& Obesitas & 25 & $14121,8 \pm 1771,6$ & 0,074 \\
hs-CRP $(\mathrm{ng} / \mathrm{ml})$ & Derajat PMS Ringan & 25 & $4077,1 \pm 790,9$ & 0,052 \\
& Derajat PMS Sedang & 25 & $21871,3 \pm 2126,0$ & 0,070 \\
\hline
\end{tabular}

Tabel 2 diketahui bahwa rerata kadar hsCRP pada Indeks Massa Tubuh (IMT) obesitas yaitu $14121,8 \pm 1771,6 \mathrm{ng} / \mathrm{ml}$ lebih tinggi dibandingkan IMT normal yaitu $1150,1 \pm 278,8$ $\mathrm{ng} / \mathrm{ml}$. Selisih rerata kadar hs-CRP antara IMT obesitas dan normal yaitu $12971,1 \mathrm{ng} / \mathrm{ml}$. Hasil uji statistik independent $T$ test didapatkan nilai $\mathrm{p}=0,001 \quad(\mathrm{p}$ value $<0,05)$ maka dapat disimpulkan terdapat perbedaan rerata dimana

576 Perbedaan Kadar HS-CRP Menurut Indeks Massa Tubuh dan Derajat Pramenstrual Syndrome pada Remaja Usia $18-24$ Tahun 
kadar hs-CRP lebih tinggi pada remaja dengan obesitas dibanding IMT normal.

Tabel 2. Perbedaan Rerata Kadar hs-CRP pada Indeks Massa Tubuh Remaja Obesitas dan Normal

\begin{tabular}{ccccc}
\hline Variabel & $\begin{array}{c}\text { Indeks Massa Tubuh } \\
\text { Obesitas } \\
(\text { Mean } \pm \text { SD) }\end{array}$ & $\begin{array}{c}\text { Normal } \\
\text { (Mean } \pm \text { SD) }\end{array}$ & $\begin{array}{c}\text { Beda } \\
\text { Rerata }\end{array}$ & p value \\
\hline Kadar hs-CRP $(\mathbf{n g} / \mathbf{m l})$ & $14121,8 \pm 1771,6$ & $1150,1 \pm 278,8$ & 12971,1 & 0,001 \\
\hline
\end{tabular}

Tabel 3 diketahui bahwa rerata kadar hsCRP pada derajat PMS ringan yaitu 4077,1 \pm $790,9 \mathrm{ng} / \mathrm{ml}$ lebih rendah dibandingkan sedang yaitu $21871,3 \pm 2126,0 \mathrm{ng} / \mathrm{ml}$. Selisih rerata kadar hs-CRP antara derajat PMS sedang dan ringan yaitu $17794,2 \mathrm{ng} / \mathrm{ml}$. Hasil uji statistik independent $T$ test didapatkan nilai $\mathrm{p}=0,027$ ( $\mathrm{p}$ value $<0,05$ ) maka dapat disimpulkan terdapat perbedaan rerata dimana kadar hs-CRP lebih tinggi pada derajat PMS sedang dibanding derajat PMS rendah.

Tabel 3. Perbedaan Rerata Kadar hs-CRP pada Derajat Pramenstrual Syndrome

\begin{tabular}{ccccc}
\hline Variabel & \multicolumn{2}{c}{ Derajat PMS } & Beda & p value \\
& $\begin{array}{c}\text { Ringan } \\
(\text { Mean } \pm \text { SD) }\end{array}$ & $\begin{array}{c}\text { Sedang } \\
(\text { Mean } \pm \text { SD) }\end{array}$ & Rerata & \\
\hline Kadar hs-CRP $(\mathbf{n g} / \mathbf{m l})$ & $4077,1 \pm 790,9$ & $21871,3 \pm 2126,0$ & 17794,2 & 0,027 \\
\hline
\end{tabular}

Tabel 4 menunjukkan bahwa persentase responden derajat PMS sedang lebih tinggi pada responden dengan obesitas yaitu $(90 \%)$ dibandingkan yang normal (10\%). Hasil uji statistik chi-square didapatkan nilai $\mathrm{p}=0,013(\mathrm{p}$ value $<0,05)$ maka dapat disimpulkan terdapat hubungan yang bermakna antara Indeks Massa Tubuh dengan derajat pramenstrual syndrome.

Tabel 4. Hubungan Indeks Massa Tubuh (IMT) dengan Derajat Pramenstrual Syndrome (PMS)

\begin{tabular}{|c|c|c|c|c|c|c|c|}
\hline \multirow{4}{*}{ IMT } & \multicolumn{4}{|c|}{ Derajat PMS } & \multirow{2}{*}{\multicolumn{2}{|c|}{ Jumlah }} & \multirow{4}{*}{$p$ value } \\
\hline & \multirow{2}{*}{\multicolumn{2}{|c|}{ Sedang }} & \multirow{2}{*}{\multicolumn{2}{|c|}{ Ringan }} & & & \\
\hline & & & & & & & \\
\hline & f & $\%$ & f & $\%$ & f & $\%$ & \\
\hline Obesitas & 9 & 90 & 16 & 40 & 25 & 100 & \\
\hline Normal & 1 & 10 & 24 & 60 & 25 & 100 & 0,013 \\
\hline Jumlah & 10 & 100 & 40 & 100 & 50 & 100 & \\
\hline
\end{tabular}

Tingginya kadar hs-CRP pada penelitian IMT dengan obesitas dibanding IMT normal lebih tinggi disebabkan karena respon inflamasi dari simpanan energi yang menghasilkan jaringan adiposa yang berlebih pada penderita obesitas yang dapat memicu terbentuknya inflamasi kronik. Kondisi ini memicu aktifasi sitokin pro inflamasi yang dapat memicu pembentukan CRP di hati.

Pengukuran High Sensitivity C-Reactive Protein (hsCRP) yang merupakan suatu uji yang lebih C-Reactive Protein (CRP) adalah suatu protein yang diproduksi oleh hati yang merupakan penanda dimana akan meningkat pada kondisi inflamasi dan juga meningkat pada keadaan infeksi atau injury. Peningkatan hs-CRP sebagai penanda proses inflamasi/ peradangan berhubungan dengan kegemukan (Schulz, 2011).
Berdasarkan teori inflamasi, pada keadaan obesitas terjadi gangguan keseimbangan adipositokin yang dilepaskan. Sel adiposit berusaha mempertahankan keseimbangan energi dengan melepaskan IL-6, TNF $\alpha$ dan Monocyte Chemoattractant Protein-1 (MCP-1). Pelepasan sitokin tersebut menandai awal inflamasi. Obesitas dapat dikatakan merupakan bentuk inflamasi kronik. Interleukin 6 dan TNF $\alpha$ dapat memicu pembentukan CRP di hati (Ridker, 2003; Pusparini, 2007). Pembentukan CRP dapat merugikan dinding arteri karena meningkatkan inflamasi pada sel endotel (Verma, 2002; Wang, 2003).

Berdasarkan analisis peneliti terdapatnya perbedaan kadar hs-CRP pada IMT dengan obesitas lebih tinggi dibandingkan normal disebabkan karena respon inflamasi yang terjadi sebagai akibat dari simpanan energi yang

Perbedaan Kadar HS-CRP Menurut Indeks Massa Tubuh dan Derajat Pramenstrual Syndrome pada Remaja Usia 18-24 Tahun 
menghasilkan adipositokin dari penderita obesitas dapat memicu bentuk inflamasi kronik. Kondisi tersebut memicu aktifasi sitokin pro inflamasi yaitu Interleukin 6 dan TNF $\alpha$ yang dapat memicu pembentukan CRP di hati. Oleh karena itu hasil penelitian ini menitikberatkan bahwa program penurunan berat badan pada responden obesitas dapat berpengaruh pada penurunan sitokin pro-inflamasi dan kadar hsCRP yang berbanding lurus setelah berat badan menurun.

Pada penelitian ini rendahnya kadar hsCRP pada derajat PMS ringan dibanding derajat PMS sedang disebabkan meningkatnya kadar hormon estrogen pada responden dengan PMS sedang yang menyebabkan terjadinya peningkatan sitokin pro inflamasi yang didukung terlebih dahulu dengan peningkatan prostaglandin, pada kondisi ini aktifasi sitokin inflamasi mendukung peningkatan kadar hs-CRP di hati sebagai salah satu marker nyeri yang merupakan salah satu kondisi dari pramenstrual syndrome.

Berdasarkan analisis terdapatnya perbedaan kadar hsCRP dengan derajat pramenstrual syndrome disebabkan oleh faktor hormonal yang merupakan faktor dominan penyebab premenstrual syndrome yaitu meningkatnya kadar estrogen. Sumber pembuatan estrogen itu sendiri adalah lemak tubuh terutama lemak dijaringan perifer yang dapat diprediksi dengan pengukuran indeks massa tubuh.

Terdapatnya hubungan IMT dengan derajat PMS disebabkan karena pada IMT dengan obesitas memiliki massa lemak tubuh yang besar dan memiliki simpanan energi yang menghasilkan adipositokin dan molekul proinflamasi seperti interleukin-6 (IL-6) yang merupakan determinan utama ekspresi gen CRP. Kondisi obesitas yang terlihat pada jaringan adipose dapat mengeskpresikan mediatormediator inflamasi (TNF $\alpha$, IL-6, IL-1), mediator ini menunjukkan bahwa mekanisme inflamasi bersinergi terhadap keluhan nyeri yang dirasakan pada wanita PMS.

Berdasarkan analisis peneliti terdapatnya hubungan indeks massa tubuh dengan derajat pramentrual syndrome disebabkan apabila indeks massa tubuh tinggi maka lemak yang dihasilkanpun semakin meningkat. Dalam hal ini, kandungan lemak yang meningkat dalam tubuh akan menghasilkan hormon estrogen yang melebihi kebutuhan sehingga akan mempengaruhi kejadian sindroma premenstruasi.
Oleh karena itu perlu adanya diet dengan memperhatikan konsumsi lemak dan energi pada penderita obesitas agar dapat mengontrol berat badan dan menjaganya dalam kondisi ideal, sehingga dapat mengurangi peningkatan keluhan pada pramenstrual syndrome.

\section{SIMPULAN}

Berdasarkan penelitian dapat disimpulkan bahwa kadar hs-CRP lebih tinggi pada remaja dengan obesitas dibandingkan IMT normal, kadar hs-CRP lebih tinggi pada derajat PMS sedang dibandingkan PMS ringan dan terdapat hubungan yang bermakna antara Indeks Massa Tubuh (IMT) dengan derajat pramenstrual syndrome.

\section{DAFTAR PUSTAKA}

Evans J, Salamonsen LA. 2012. Inflammation, leukocytes and menstruation. Rev Endocr Metab Disord ;13:277-288.

Berbic M, Ng CH, Fraser IS. 2014. Inflammation and endometrial bleeding. Climacteric. 2:47-53.

Liebregts T, Adam B, Bredack C, et al. 2007. Immune activation in patients with irritable bowel syndrome. Gastroenterology 132:913-920.

Puder,J.J., Blum,C.A., Mueler, B., et al. 2006. Menstrual cycle symptoms are associated with changes in low - grade inflammation. $36(1): 58-64$.

Gold, EB., Wells, C., Rasor, MO. 2015. The Association of Inflammation with Premenstrual Symptoms. Journal Of Women's Health Volume 25, Number 9, 2016. DOI: 10.1089/jwh.2015.5529

Gansareng, D dkk. 2015. Hubungan Antara Ketebalan Lemak dan Kadar High Sensitive C Creative Protein (hs-CRP) pada Mahasiswa Obes dan Tidak Obes di Fakultas Kedokteran Sam Ratulangi Manado. Jurnal e-Biomedik (eBm), Volume 3, Nomor 1, Januari-April 2015.

Capuron,L., Poitou,C., Machaux-Tholliez D. et al. 2010. Relationship between adiposity, emotional status and eating behaviour in obese women: role in inflammation. 41 (7): $1517-28$.

Wunder, D.M., Yared, M., Bersinger,N.A., Widmer, D., Kretshmer R., 2006. Serum Leptin And C-Reactive Protein Levels In The Physiological Spontaneuous Menstrual Cycle In Reproductive Age 
Women. European Journal of Endocrinology.155. 137 - 142.

Schulz. R., Gerd Heusch. 2011. C-Reactive Protein Just a Biomarker Of inflammation or a Pathophysiological Player On a Miocardial Function and Morphology? (Online). (http://hyper.ahajournals.org/ Diakses 22 Maret 2016).

Ridker MP. 2003. C-reactive protein: a simple test to help predict risk of heart attack and stroke. Circulation. 108:e81.

Pusparini. 2007. Obesitas sentral, sindroma metabolik dan diabetes mellitus tipe dua. Universa Medicina. 26:195-204.

Verma S, Li SH, Badiwala MV, Weisel RD, Fedak PW, Li RK, Dhillon B, Mickle DA. 2002. Endothelin antagonism and interleukin-6 inhibition attenuate the proatherogenic effects of c-reactive protein. Circulation. 105:1890-96.

Wang $\mathrm{CH}$, Li SH, Weisel RD, Fedak PW, Dumont AS, Szmitko P, Li RK, Mickle DA, Verma S. 2009. C-reactive protein upregulates angiotensin type 1 receptors in vascular smooth muscle. Circulation. 107:1783-90. 